\title{
Ecosystem impacts of folivory and frugivory by Japanese macaques in two temperate forests in Yakushima.
}

\section{$\operatorname{AUTHOR}(\mathrm{S}):$}

Hanya, Goro; Fuse, Mieko; Aiba, Shin-Ichiro; Takafumi, Hino; Tsujino, Riyou; Agetsuma, Naoki; Chapman, Colin A

\section{CITATION:}

Hanya, Goro ...[et al]. Ecosystem impacts of folivory and frugivory by Japanese macaques in two temperate forests in Yakushima.. American journal of primatology 2014, 76(6): 596607

\section{ISSUE DATE:}

2014-06

URL:

http://hdl.handle.net/2433/199864

\section{RIGHT:}

This is the peer reviewed version of the following article: Hanya, G., Fuse, M., Aiba, S.-I., Takafumi, H., Tsujino, R., Agetsuma, N. and Chapman, C. A. (2014), Ecosystem impacts of folivory and frugivory by Japanese macaques in two temperate forests in Yakushima. Am. J. Primatol., 76: 596-607, which has been published in final form at http://dx.doi.org/10.1002/ajp.22253. This article may be used for non-commercial purposes in accordance with Wiley Terms and Conditions for Self-Archiving.: この論文は著者最終稿です。内容が印刷版と異なることがありますので、引 用の際には出版社版をご確認ご利用ください。This is the Accepted Author Manuscript. Please cite only the published version. 
1 Ecosystem impacts of folivory and frugivory by Japanese macaques in two

2 temperate forests in Yakushima

3

4 GORO HANYA ${ }^{*}$, MIEKO FUSE $^{2}$, SHIN-ICHIRO AIBA ${ }^{3}$, HINO TAKAFUMI $^{4}$,

5 RIYOU TSUJINO ${ }^{5}$, NAOKI AGETSUMA ${ }^{6}$ and COLIN A. CHAPMAN ${ }^{7}$

6

$7 \quad{ }^{1}$ Primate Research Institute, Kyoto University, Inuyama, Japan

82 Sasayama Field Station, Kobe University, Sasayama, Japan

$9 \quad{ }^{3}$ Kagoshima University, Kagoshima, Japan

$10 \quad{ }^{4}$ Rakuno Gakuen University, Ebetsu, Japan

$11{ }^{5}$ Nara University of Education, Nara, Japan

$12{ }^{6}$ Field Science Center for Northern Biosphere, Hokkaido University, Kozagawa,

13 Japan

$14{ }^{7}$ Department of Anthropology and McGill School of Environment, McGill

15 University, Montréal, Canada and Wildlife Conservation Society, Bronx, NY, USA 16

17 Short title: Primate ecosystem impact

18

$19{ }^{*}$ Correspondence to: GORO HANYA

20 Primate Research Institute, Kyoto University, Inuyama, Aichi, 484-8506, Japan.

21 E-mail: hanya@pri.kyoto-u.ac.jp

22 Tel: +81-568-63-0542

23 Fax: +81-568-63-0564 
Hanya et al.

Primate impact

\section{Abstract}

26 Comparing animal consumption to plant primary production provides a means of assessing an animal's impact on the ecosystem and an evaluation of resource limitation. Here we compared annual fruit and leaf consumption by Japanese macaques (Macaca fuscata) relative to the annual production of these foods in the lowlands and highlands of Yakushima Island, Japan. We estimated consumption by macaques by the direct observation of macaques groups for one year in each habitat. We estimated leaf production as the sum of leaf litter fall (corrected for the effect of translocated organic and inorganic matter) and folivory by insects (assumed to be $10 \%$ ) and by macaques. We estimated fruit production as the sum of fruit litter fall and consumption by birds (estimated by the seed fall) and macaques. The impact of macaque folivory at the community level was negligible relative to production ( $0.04 \%)$ compared with folivory by insects (assumed to be 10\%); however, for some species, macaque folivory reached up to $10.1 \%$ of production. Tree species on which macaques fed did not decline in abundance over 13 years, suggesting that their folivory did not influence tree species dynamics. For the three major fleshy fruited species in the highland site, macaques consumed a considerable portion of total fruit production (6-40\%), rivaling the consumption by birds (32-75\%). We conclude that at the community level, macaque folivory was negligible compared to the leaf production, but frugivory was not.

Keywords: primary production, primate, productivity, resource limitation, temperate forest 


\section{INTRODUCTION}

50 Animals depend on plant production to sustain their populations, and animals

51 can affect plants through pollination [Yumoto 1987], seed dispersal [Howe 1986]

52 and predation on seeds, flowers and leaves [Adams et al. 2009; Sun et al. 2007].

53 The effects of plants on animals are usually understandable and well-studied

54 [Chapman et al. 2010; Hanya et al. 2011], but the impact of animal consumption

55 on plant primary production is scarcely quantified. Comparing animal

56 consumption to plant production provides both a useful mean of assessing the

57 ecosystem impact of animals and a way of evaluating if their populations are

58 resource limited. There is substantial correlative evidence that animal

59 populations are limited by plant productivity [Hanya et al. 2004; Hanya \&

60 Chapman 2013; Stevenson 2001] and direct tests of food limitation involving

61 food removal or provisioning have also been conducted [Adler 1998;

62 Moegenburg \& Levey 2003]. However, an experimental approach is not

63 feasible for animals ranging over a wide area or having a diverse diet, such as

64 most primates [Hanya \& Chapman 2013]. For some primates there is

65 considerable controversy concerning whether they are limited by food resources

66 or if such resources are superabundant. For example, Coelho et al. [1976]

67 estimated that fruit production far exceeded the food intake for two primates and

68 concluded the populations were not food limited. This study was criticized

69 because it included only 2 months of data, and did not address nutritional

70 requirements [Cant 1980]. Similarly, many researchers often assume that tree

71 leaves are as superabundant for folivores, but there is increasing evidence that

72 folivores compete over access to the best leaves and thus that these food item

73 can be limiting [Koenig 2002; Snaith \& Chapman 2007]. 
Hanya et al.

Primate impact - 4 -

74

75

76

77

78

79

80

81

82

83

84

85

86

87

88

89

90

91

92

93

94

95

96

97

98

Large animals are often the most endangered species in an ecosystem [Corlett 2009; Primack 1995], thus, it is important to understand the ecosystem services they provide and to predict the impact of their disappearance. For example, extinction of large primates alters tree species composition as large-seeded plants, which depend on primate dispersers, are not dispersed [Chapman \& Onderdonk 1998; Nuñez-Iturri \& Howe 2007]. Some ecosystem services will be taken on by other animals with overlapping feeding niches [Peres \& Dolman 2000], but it is difficult to predict which services will remain as the functional redundancy is affected by various factors [Rosenfeld 2002]. Therefore, it is necessary to assess the relative impact of various animals on forest productivity.

We aimed to compare the fruit and leaf biomass consumed by Japanese macaques (Macaca fuscata), folivorous insects and frugivorous birds, with the leaf and fruit production over 1 year on Yakushima, Japan. Our study sites included a warm- and a cool-temperate forest, which differ with respect to fruit production, macaque density, and diet [Hanya et al. 2003a; Hanya 2004; Hanya et al. 2004]. We also assessed the effect of macaques' folivory on forest tree species composition over 13 years.

\section{METHODS}

The research complied with protocols approved by the Primate Research Institute, Kyoto University and it adhered to the legal requirements of Japan and to the American Society of Primatologists Principles for the Ethical Treatment of Non Human Primates. 


\section{Study sites and subjects}

100 We studied in highland (coniferous cool- temperate, 1000-1200 m a.s.I.) and

101 lowland (evergreen broad-leaved warm-temperate, 0-200 m a.s.l.) forests separated by $7 \mathrm{~km}$ on the island of Yakushima $\left(30^{\circ} \mathrm{N}, 131^{\circ} \mathrm{E}\right)$, Japan. We observed the feeding behavior of the HR group in the highland site and the NA and $\mathrm{H}$ groups in the lowland site. The annual home ranges of the HR, NA, and $\mathrm{H}$ groups were $2.7,0.6$, and $0.7 \mathrm{~km}^{2}$, respectively. The home range of the HR group was a mosaic of primary and logged forest, but primary forest, where forest productivity was studied, comprised $83 \%$ of the total area. The home ranges of $\mathrm{NA}$ and $\mathrm{H}$ groups overlapped extensively and consisted of old secondary forest. Hanya [2004] and Hanya et al. [2007] provide further information about the study sites and subjects. macaques [Agetsuma et al. 2003] and they influence forest dynamics [Koda et al.

113 2008]. However, we did not compare their impact because deer eat leaves

114 from the ground, where the productivity cannot be estimated by litter trap. In addition, they eat a considerable amount of dead leaves [Agetsuma et al. 2011] they are thus often acting as decomposers. There are no other folivorous or

117 frugivorous large mammals in the island. Marten (Mustela itatsi) and field mice

118 (Apodemus speciosus and A. argenteus) may also eat fruits, but they were also not considered as they are terrestrial. Their biomass seems negligible compared with that of macaques because they are very small ( $\sim 2 \mathrm{~kg}$ for martens and 20-60 g for mice) and very rare, considering the much lower photographic rate (1/10 of macaques) in camera trapping (Hanya et al., unpublished data). 


\section{Behavioral observations}

125 We collected data between April 2000 and March 2001 for HR group in the

126 highland site (510 hr) and between October 2003 and August 2004 for NA group

127 in the lowland site $(1080 \mathrm{hr})$. To supplement the September data lacking for the

128 NA group, we also used the data of $\mathrm{H}$ group in September 1998. We collected

129 behavioral data using focal animal sampling (duration of $1 \mathrm{hr}$ ) of seven adult

130 females and six males for the highland group (mean \pm SD of observation time:

$13139 \pm 12 \mathrm{hr} / \mathrm{individual}$ ), and five adult females for the NA group (216 \pm 75

$132 \mathrm{hr} /$ individual) and for five adult males in the $\mathrm{H}$ group (18 $\pm 0.86 \mathrm{hr} /$ individual).

133 Data on the diet are available elsewhere [Hanya 2003; Hanya 2004; Hanya et al.

134 2007] (Appendix 1). We defined a feeding bout as starting when the animal put

135 food into the mouth and stopping when 20 seconds had elapsed without the

136 subject moving in the tree or manipulating food or when the animal left the tree

137 or started eating other items. We recorded the number of food units that the

138 animal ingested for as long as possible. One food unit was operationally

139 defined depending on the particular item and plant species (e.g. one leaf, one

140 fruit, one cluster of fruits).

141

\section{Estimating food consumption}

143 We estimated the dry weight intake of all stages of leaves (both mature and

144 young leaves) and fruits (including seeds). We considered consumption as the

145 removed biomass and included the weight of indigestible parts that were

146 discarded before ingestion. For feeding bouts where the number of food units

147 ingested could not be recorded, we estimated ingestion by multiplying the

148 duration of the feeding bouts and the average feeding rate (\#units/second) of all 
149 feeding bouts for that item of the species. To calculate this average, we

150 discarded data when the duration of a feeding bout was less than 2 min unless

151 this was the only datum available for the food species/item. This was because 152 data of short duration were less reliable. Then, we multiplied the number of

153 food units ingested (estimated or actually counted) during each feeding bout by

154 its unit dry weight and summed the results for all feeding bouts of each focal

155 observation. We multiplied the estimated dry weight intake per observation

156 hour with the average day length of the month and the number of days in the 157 month, to obtain the total estimated dry weight intake in the month. This could

158 be justified as the distribution of observations was not biased to a particular time 159 of the day or month: we made from dawn to dusk [Hanya 2004; Hanya et al. 160 2007] and equally distributed observation days in each month. We calculated 161 total annual intake by summing the values of the 12 months. We summarized 162 data of the unit weight and feeding rate in Appendix 2. We estimated intake for age-sex classes that we did not observe assuming that macaque consumption was proportional to the 0.75 power of average body mass for the age/sex [Kleiber 1987] using body weight data from Watanabe [1975] (Appendix 3). For the highland site, data on adult males and

167 females were available, so we estimated the average intake using the pooled 168 data. For the lowland site, only the female data were available, so we 169 estimated the male intake following the power rule. We used age-sex 170 composition of the HR and NA groups to estimate the proportion of individuals of 171 each age-sex class in the population. We used the data of these two particular 172 groups, rather than the data on age-sex composition collected over a larger 173 scale. This was because we needed to use data that were comparable with the 
174 behavioral and litter trap data, which were taken within the home range of these

175 two particular groups. We calculated food consumption of each age-sex class

176 at the population level by multiplying (1) the estimated food consumption of the

177 class, (2) proportion of the class in the population and (3) the population density.

178 We derived density from Yoshihiro et al. [1999] and Hanya et al. [2003b]

179 (Appendix 3). We calculated food consumption at the population-level as the sum of all the age-sex classes. In the highland site, we also recorded the amount of leaves that macaques dropped during feeding. We estimated total amount of dropped leaves in that month by an adult individual by multiplying the amount of leaves (g) per observation time, average day length of the month and the number of days in the month. We estimated amount dropped at the population level over the year in the same way as we did for leaf intake.

\section{Litter trap}

We established two vegetation plots within the home ranges of the groups and identified and measured all tree stems with a diameter at breast height $(\mathrm{DBH})>$

$1905 \mathrm{~cm}$. Plot size was $50 \mathrm{~m} * 50 \mathrm{~m}$ in the highland site $(0.09 \%$ of the home range of the HR group) and $100 \mathrm{~m} * 50 \mathrm{~m}$ in the lowland site $(0.8 \%$ of the home range of the NA group). Aiba et al. [2007] and Hanya and Aiba [2010a] described details of the plots. These plots included both ridge and valley and phenological change recorded in these plots predicted the seasonal variation in the macaque diet [Hanya 2004; Hanya et al. 2007]. Therefore these plots seemed to be representative of the home range. We placed 25 and 20 litter traps (nylon mesh of $<0.5 \mathrm{~mm}, 0.58 \mathrm{~m}^{2}$ in size and 1-1.5 $\mathrm{m}$ above the ground) evenly distributed in highland and lowland site plots respectively. The minimum 
199

200

201

202

203

204

205

206

207

208

209

210

211

212

213

214

215

216

217

218

219

220

221

222

inter-trap distance was $10 \mathrm{~m}$. We collected litter once a month, oven-dried it at $60{ }^{\circ} \mathrm{C}$ for $96 \mathrm{hr}$ and weighed and sorted items into broad-leaf, conifer needle, fruits, and others. Fruits included the whole or partial ripe fruits, unripe fruits and seeds separated from pulp. We sorted them by species and weighed them. We separated bird feces from 'others' in the highland plot.

\section{Estimation of fruit and leaf production}

We conducted the species-level analysis of leaf and fruit consumption for species that accounted for at least $1 \%$ of the annual feeding time in each area and when the fruit or leaf production of these species could be estimated by fruit fall or tree species composition in the plots. In addition to these species, we also examined fruit consumption of three fleshy-fruited species in the highland site (Eurya japonica, Cleyera japonica, and Symplocos myrtaceae), because we could also estimate bird consumption for these species.

Leaf production: We converted litter fall to $\mathrm{kg} / \mathrm{ha} / \mathrm{year}$ by dividing the total annual weight of litter by total litter trap area. We could estimate the weight of leaf litter for particular species from the data of relative basal area of the species because the relative basal area and leaf litter of each tree species was positively correlated $(r=0.81, p<0.0001, N=37$ species, data from the lowland plot for one year from December 2004). Therefore, when we estimated leaf fall for each species, we assumed that the leaf litter weight of a species was proportional to the species basal area relative to the total basal area in the plot. In principle, annual leaf production is equal to annual leaf litter fall when the leaf biomass of the forest reaches equilibrium [Clark et al. 2001]. However, 
224 these two values are not necessarily the same because of (1) translocation of

225 organic and inorganic matter from the abscised leaves and (2) herbivory. Mean

226 leaf mass loss for temperate evergreen angiosperm leaves is $20.8 \%$ [Vergutz et

227 al. 2012], so we divided the gross leaf litter fall by (1-0.208) to estimate the

228 biomass of leaves before falling to the trap. Hereafter, we refer this value as

229 'corrected leaf fall'. We assumed the amount of insect herbivory as $10 \%$ of the

230 leaf production, which is a mean value for temperate forests [Landsberg \&

231 Ohmart 1989] (3-17\%). We calculated the leaf production as the sum of

232 corrected leaf fall and consumption by macaques and insects, which are the only

233 animals that eat leaves in the canopy layer on Yakushima.

235 Fruit production: We calculated the production of fruit for the highland site as the sum of fruit fall and consumption by macaques and birds. However, in the

237 lowland site, data on bird consumption were lacking so macaque frugivory was

238 compared only with the fruit fall. The current estimation in the highland was

239 based on the data used also in Hanya [2005], who calculated only the total

240 number of seeds removed by birds. However, in the current analysis, we

241 present data for each species of plant. We confined the estimation of bird

242 consumption to the three species (E. japonica, C. japonica, and S. myrtaceae)

243 that constituted $92.5 \%$ of the fleshy fruit production in the highland site. These

244 species have small seeds ( $<5 \mathrm{~mm}$ long) which were swallowed by macaques

245 [Otani \& Shibata 2000]. Thus, in the estimation, we could regard the pulpless

246 seeds of these species dropped into the trap as having dispersed by birds

247 [Kominami et al. 2003], along with the seeds found in bird feces. We did not

248 find any macaque feces in the traps in the highland site. We confirmed that 
macaque feces were recognizable for at least one month after defecation by experimentally putting feces in a trap. We estimated the weight of fruits removed by birds using the data of (1) the number of seeds trapped, (2) the average number of seeds in one fruit for each species and (3) average weight of one fruit, of which data we collected by measuring $>100$ fruits for each species.

\section{Long-term changes of forest composition}

To assess the impact of macaque folivory on forest tree species dynamics, we established a 2.4 ha vegetation plot ( $4 \%$ of the home range of the NA group) in 1990 in the lowland site. The plot consisted of 10 line transects ( $5 \mathrm{~m}$ wide, 30-150 m long) set every $100 \mathrm{~m}$ within the entire home range of the NA and the $\mathrm{H}$ groups. We recorded the species and the $\mathrm{DBH}$ of all trees $>5 \mathrm{~cm} \mathrm{DBH}$ in 1990 and 2003. In the highland site, for the analysis of forest composition dynamics, we used the plot of 0.25 ha that we set to collect litter. We established this plot in 1999 and resampled in 2012. We examined changes in density between the two periods using a G-test for species with more than 9 stems in one of the years. We tested a null hypothesis which assumed no difference in the proportion of decreasing species between food and non-food species. We examined 47 lowland (5 food and 42 non-food species) and 10 highland species (3 food and 7 non-food species).

\section{RESULTS}

\section{Folivory}

272 In both the lowland and highland sites, the impact of macaque folivory at the 273 community level was negligible relative to leaf production or assumed folivory by 
274 insects. The leaf biomass consumed by macaques was only $0.037 \%$ and

$2750.39 \%$ of the estimated total leaf production in the lowland and highland sites,

276 respectively (Table 1 ). These values increased if we considered only food

277 species, but it still remained low $(0.21 \%$ in the lowland site and $0.90 \%$ in the

278 highland site). At the species level, however, macaque leaf consumption

279 reached $5.7 \%$ of the estimated leaf production in the lowland site

280 (Daphniphyllum teijsmannii) and $10.1 \%$ in the highland site (Symplocos

281 prunifolia). For other species, macaques consumed between $0.93 \%$ and

$2822.14 \%$ of the leaves produced. In the highland site, we estimated the biomass

283 of dropped leaves as $3.93 \mathrm{~kg} / \mathrm{km}^{2} /$ year, which was $0.21 \%$ of the consumed 284 leaves.

There was no evidence that macaque food trees died at a greater rate than non-food trees over the 13 years of monitoring (Table 2). In the lowland site, the proportion of decreasing species was not different between the food and non-food species ( $G=0.50 ; p=0.48)$. None of the species decreased in abundance at the highland site.

\section{Frugivory}

292 In contrast to leaves, macaques consumed a considerable portion of the total 293 fruit production. For the three fleshy-fruited species in the highland site, for 294 which we quantified both bird and macaque consumption, macaque 295 consumption was 3.2-39\% of the total fruit production depending on plant 296 species, whereas birds consumed between 32 and $75 \%$ of the fruit production 297 (Table 3b). Macaques and birds together consumed more than two-thirds of 298 the fruit production for all the species. In the lowland site, fruit consumption by 
macaques constituted $8.8 \%, 10.1 \%$, and $68.8 \%$ of fruit fall for all species, food species, and the most frequently eaten species, respectively (Table 3a).

Although there were 12 fruiting species that constituted more than $1 \%$ of the annual feeding time (sum of the duration of the feeding bouts) for the lowland site macaques, fruits of only one of them appeared in the litter trap.

\section{DISCUSSION}

Impact of folivory and its effect on long-term forest dynamics

Our data suggested that at the community level the amount of leaves consumed by Japanese macaques in Yakushima was negligible compared with the leaf production. Total leaf consumption by macaques constituted less than $0.4 \%$ of the total leaf production. However, for some species, the impact of macaque folivory reached $10 \%$ in the highland site, which was comparable to the community-level impact of insect folivory known for various types of forests

313 (3-17\%) [Landsberg \& Ohmart 1989]. Because some tree species can survive even if they lose all their leaves by browsing [Rooke \& Bergstrom 2007], we need further study to confirm the effect of folivory on plant longevity, growth, and/or reproduction.

Species whose leaves were eaten by macaques did not decrease in abundance over 13 years. However, it is still possible that some species are negatively affected by overgrazing by macaques. For example, Daphniphyllum teijsmannii, which was the most extensively eaten species in the lowland site, decreased in number from 182 to $133(G=7.65, p=0.0057)$. However, this species is not shade-tolerant [Aiba et al. 2001] thus the decrease was likely caused by the lack of forest disturbance. 
In contrast to our results, Chapman et al. [2013] reported that in Kibale

National Park, Uganda, there was a tendency for tree species that were eaten by two species of colobus monkeys to decrease in abundance but no such tendency was found for the species that colobus did not eat. The difference between Yakushima and Kibale is likely due to difference in primate biomass. Primate biomass in Kibale (2759 kg/km²) [Chapman et al. 1999] is 6.77 and 24.2 times larger than that in the lowland and highland sites of Yakushima respectively and folivorous colobines make up the greatest portion (75\%) of that biomass [Chapman et al. 1999]. Total litter fall (including leaves, branch, and reproductive parts) in Yakushima was 565,000 kg/km²/year in the lowland site and $473,000 \mathrm{~kg} / \mathrm{km}^{2} / y e a r$ in the highland site. This represented $71 \%$ and $59 \%$ of the average documented for 12 tropical forests (average $=966,200 \mathrm{~kg} /$ km²/year, maximum: 1,235,000 kg/ km²/year) [Hanya \& Aiba 2010b]. Therefore, if we suppose that leaf production in Kibale is average for a tropical forest, leaf production in Kibale is calculated only as 1.41 times larger than that in the lowland site and 1.69 times of that in the highland site of Yakushima.

340 Supposing further that the amount of leaf consumption is proportional to primate 341 biomass; leaf consumption/production ratio in Kibale is $4.80(6.77 / 1.41)$ times 342 larger than in lowland site and $17.1(24.2 / 1.41)$ times larger than in the highland 343 site of Yakushima. Given that $75 \%$ of the primate biomass in Kibale is 344 folivorous colobines, this is likely to be a conservative estimate. That is, if 345 Japanese macaques in Yakushima consume ca. 10\% of produced leaves for some species, more folivorous Kibale primates would impose more serious damage to many species. In addition, latitudinal variations in leaf turn-over cycle [Reich et al. 1996] may affect the different impact of folivory in Yakushima 
349 (temperate) and Kibale (tropical). More detailed data on leaf production and 350 consumption by Kibale primates are needed to confirm our estimates. In any 351 case, however, comparisons of Yakushima and Kibale suggest that the threshold 352 value of primate biomass above which primate folivory has a critical impact on 353 the forest lies somewhere between Yakushima and Kibale.

\section{Impact of frugivory}

356 Of the three fleshy-fruited species evaluated at the highland site, Japanese

357 macaques were the most important fruit consumer for one ( $E$. japonica),

358 consuming approximately $40 \%$ of production. As for the two other species, bird 359 consumption was 11-23 times larger than that of macaques. These two groups 360 of frugivores consumed up to two thirds of the fruit production. Although one 361 third of the fruits were not eaten, we think that fruits may nevertheless be a 362 limited resource. According to our data on the seasonality of fruit fall, a majority $363(91 \%)$ of the uneaten fruits of these species dropped before the macaques and 364 birds stop feeding on them (by November) and it appeared that finding fruits was 365 difficult. When frugivores stopped feeding on these fruits, there were only very 366 few fruits remaining. In addition, considering the degree of inter-annual 367 variability in diet, frugivores could have depleted the uneaten fruit biomass. 368 Hanya [2005] showed that the fruit consumption by macaques and birds in 1999 369 reached 1.66 times higher than in 2000. Tsuji et al. [2006] reported even higher 370 inter-annual variation in the amount of fruits consumed by wild Japanese 371 macaques in Kinkazan, northern Japan.

372 The impact of macaque frugivory at the community level remains to be 373 further investigated, but we can expect that it would be larger than the case of 
374 folivory, but smaller than the case of intensively-fed E. japonica fruits. This is

375 because macaques consumed only $10 \%$ of the fruit fall for all the food species.

376 In addition, most (65\%) of the fruit fall for the species eaten by macaques comprised two gravity-dispersed species (Distylium racemosum and Camellia japonica) [Hanya \& Aiba 2010a], which were unlikely to be eaten by birds (Hanya, per. obs). Macaques might be seed predators for these species. We cannot fully assess the impact of the frugivory by Japanese macaques in the lowland site because there are no data on bird consumption there. For several reasons, however, it is likely that the tendency would be the same in the lowland site as in the highland sites. First, most (58\%) of the fruit fall of food species for macaques in the lowland site was acorns [Hanya \& Aiba 2010a], which most birds in Yakushima do not consume. Second, at the species level, macaques are likely important fruit consumers for some species. For example, fruits of Litsea acuminata consumed by macaques reached $68 \%$ of the fruit fall, which is a similar level to that of $E$. japonica in the highland site. Fruits of $L$. acuminata are among the largest in Yakushima and only a few bird species can swallow the seeds [Noma \& Yumoto 1997]. In addition, it has already been clarified that fruit consumption by macaques in the lowland site Yakushima is much larger (>32 times) than that by birds for two fleshy-fruited species (Ficus superba and Myrica rubra) [Otani 2001; Terakawa et al. 2008].

394 Third, 11 out of 12 major food fruit species for Japanese macaques were 'rare' species whose fruit abundance cannot be accurately estimated by litter traps. Since they are rare, the fruit production of these species is likely to be lower than the common species, such as $L$. acuminata. Therefore, the ratio of macaque frugivory to fruit production would be higher for these species than $L$. acuminata. 
399 It is already known that the Japanese macaques in Yakushima provide effective

400

401

402

403

404

405

406

407

408

409

410

411 macaques of different age classes are roughly consistent with our assumption. age-sex composition of the subject groups, which was the most likely seed dispersal services with respect to the quality, such as dispersal distance and topography [Noma \& Yumoto 1997; Otani \& Shibata 2000; Terakawa et al. 2009; Tsujino \& Yumoto 2009; Yumoto et al. 1998]. Seed dispersal effectiveness could be evaluated as the product of quantity and quality of seed dispersal [Schupp et al. 2010]. Our results suggest the quantitative importance of seed dispersal by macaques and thus suggest they play an important role in forest regeneration through seed dispersal.

\section{Robustness of the results}

Our results remain preliminary as they are based on several assumptions. Here we discuss the possible biases in the estimations and the robustness of our findings. We hope our preliminary analysis will stimulate future research in this rarely studied but important area of primate ecology.

First, although our dietary data were based on detailed observation of feeding behavior, food intake at the population level was estimated based on many assumptions. Error may have occurred when we (1) estimated food intake of one age-sex class from the data of different classes, (2) estimated age-sex composition of the population, and (3) calculated population-level intake from the population density. As for the first assumption, Hanya [2003] has confirmed that variation in the mass of food ingested by wild Japanese We believe the second assumption did not cause serious error, as we used the composition of the macaques using the area within the home ranges of the 
424

425

426

427

428

429

430

subject groups. As for the third assumption, the density data seemed correct because they agreed with the the long-term record of the distribution of identified groups [Yoshihiro et al. 1999; Hanya et al. 2003]. Error could have occurred if there was heterogeneity in density within the study site and the home range of the study group was situated where density was particularly high or low, although it seemed unlikely that this was the case given the distribution of groups in the study area.

Second, data on productivity were derived from plots of only 0.25 ha or 0.5 ha. This area was much smaller than the home ranges of the study groups, and may not reflect productivity across the entire home range area. We note, however, that productivity measured in plots within the same altitudinal zones of Yakushima differed at most by a factor of two [Aiba et al. 2007]. This difference is much smaller than the difference in leaf productivity and macaque consumption. Therefore, the qualitative conclusion of our analysis - that macaque folivory is negligible - is not likely to be affected by plot size. However, the conclusion at the population level needs further examination, as certain plant species may show a non-random in the monkeys' home range. Focal tree observation might be a better approach to assess consumption and productivity for rare species.

Third, the small plot size in the highland site constrained the analysis of tree species dynamics. Therefore, our evaluation of forest dynamics in the highland site is preliminary. However, given that none of the species decreased in abundance, it is unlikely that larger plot sizes would produce contrary findings. We cannot discard the possibility that macaques can have significant negative impact on rare species which did not appear in the vegetation plot. Various 
449 plots are established in different altitudinal zones of Yakushima [Aiba et al. 2007],

450 so meta-analysis of tree species dynamics with respect to macaque folivory will

451 be feasible in the future. The plot size in the lowland site was rather large (2.4

452 ha) and cover the entire home range, so the results from here seemed reliable.

453 Finally, there were no data from the NA group for one month, so we

454 filled in missing values with data from another year and another group.

455 Considering the large seasonal variation in the diet in Yakushima [Hanya 2004;

456 Hill], we believe this is a better solution than calculating the intake in this month

457 as an average of the other 11 months. Because the home ranges of the two

458 groups overlapped extensively, we assumed that dietary differences were

459 minimal. Main foods in this month were fruits of figs and Rhus succedanea,

460 both of which exhibit small supra-annual variations in fruiting intensity.

461 Therefore, large supra-annual variations in the diet in this month also seem

462 unlikely. In addition, the actual over- or underestimation related to using the 463 data of other year/group should be small because it constitutes only one of the 464 twelve months.

465

466 In conclusion, macaque folivory was negligible compared to leaf production at

467 the community level because macaque consumption constituted only $\sim 0.04 \%$ of

468 the leaf production and macaque food species did not decrease over 13 years.

469 However, the impact of macaque frugivory has more important consequences for 470 the plants consumed.

471

472 ACKNOWLEDGEMENTS

473 We would like to thank our friends and colleagues in Yakushima for their 
474 hospitality and help. The Sarugoya Committee and Field Research Center

475 (currently, Wildlife Research Center) of Primate Research Institute, Kyoto

476 University (KUPRI) offered us excellent facilities. The Yakushima Forest

477 Environment Conservation Center and Kirishima-Yaku (currently, Yakushima)

478 National Park gave us permission to study in the area. Dr. Marina Cords and

479 two anonymous reviewers gave us helpful comments on the manuscript. We

480 are grateful to these people and organizations. This study was financed by the

481 John Mung Program of Kyoto University, Cooperation Research Program of

482 KUPRI, the MEXT Grant-in-Aid (No. 99J04746, No. 03J04838, No. 20770195,

483 No. 22687002, No. 23657018, No. 25291100 and No. 25650145) to GH, the 21st

484 Century COE Program (A14), and Global COE Program "Formation of a

485 Strategic Base for Biodiversity and Evolutionary Research: from Genome to

486 Ecosystem". There is no conflict of interests with respect to this study.

487

\section{REFERENCES}

489 Adams JM, Zhang YJ, Basri M, Shukor N. 2009. Do tropical forest leaves suffer more insect herbivory? A comparison of tropical versus temperate herbivory, estimated from leaf litter. Ecol Res 24: 1381-1392.

Adler GH. 1998. Impacts of resource abundance on populations of a tropical forest rodent. Ecology 79: 242-254.

Agetsuma N, Agetsuma-Yanagihara Y, Takafumi H. 2011. Food habits of Japanese deer in an evergreen forest: Litter-feeding deer. Mamm Biol 76: 201-207.

Agetsuma N, Sugiura H, Hill DA, Agetsuma-Yanagihara Y, Tanaka T. 2003. 
nippon yakushimae) in an evergreen broad-leaved forest in Yakushima,

500 southern Japan. Ecol Res 18: 475-483.

501

Aiba S, Hanya G, Tsujino R, Takyu M, Seino T, Kimura K, Kitayama K. 2007.

502 Comparative study of additive basal area of conifers in forest ecosystems

503 along elevational gradients. Ecol Res 22: 439-450.

504

505

506

507

508

509

510

511

512

513

514

515

516

517

518

519

520

521

522

523

Aiba S, Hill DA, Agetsuma N. 2001. Comparison between old-growth stands and secondary stands regenerating after clear-felling in warm-temperate forests of Yakushima, southern Japan. For Ecol Manage 140: 163-175.

Cant JGH. 1980. What limits primates? Primates 21: 538-544.

Chapman CA, Bonnell TR, Gogarten JF, Lambert JE, Omeja PA, Twinomugisha D, Wasserman MD, Rothman JM. 2013. Are primates ecosystem engineers? Int J Primatol 34: 1-14.

Chapman C, Gautier-Hion A, Oates J, Onderdonk D. 1999. African primate communities: Determinants of structure and threats to survival. In: Fleagle J, Janson C, Reed K, editors. Primate Communities. Cambridge: Cambridge Univ Press. p 1-37.

Chapman CA, Onderdonk DA. 1998. Forests without primates: Primate/plant codependency. Am J Primatol 45: 127-141.

Chapman CA, Struhsaker TT, Skorupa JP, Snaith TV, Rothman JM. 2010. Understanding long-term primate community dynamics: implications of forest change. Ecol Appl 20: 179-191.

Clark DA, Brown S, Kicklighter DW, Chambers JQ, Thomlinson JR, Ni J, Holland EA. 2001. Net primary production in tropical forests: An evaluation and synthesis of existing field data. Ecol Appl 11: 371-384.

Coelho AMJ, Bramblett CA, Quick LB, Bramblett SS. 1976. Resource availability 
and population density in primates: A sociobioenergetic analysis of the 63-80.

527 Corlett RT. 2009. The Ecology of Tropical East Asia. Oxford: Oxford University $528 \quad$ Press.

529 Hanya G. 2003. Age differences in food intake and dietary selection of wild male $530 \quad$ Japanese macaques. Primates 44: 333-339.

531 Hanya G. 2004. Diet of a Japanese macaque troop in the coniferous forest of Yakushima. Int J Primatol 25: 55-71.

533 Hanya G. 2005. Comparisons of dispersal success between the species fruiting prior to and those at the peak of migrant frugivore abundance. Plant Ecol 181: $167-177$.

Hanya G, Aiba S. 2010a. Fruit fall in five warm- and cool-temperate forests in Yakushima, Japan. Forestry Studies in China 12: 184-192.

Hanya G, Aiba S. 2010b. Fruit fall in tropical and temperate forests: implications for frugivore diversity. Ecol Res 25: 1081-1090.

540 Hanya G, Chapman CA. 2013. Linking feeding ecology and population abundance: a review of food resource limitation on primates. Ecol Res 28: 183-190.

543 Hanya G, Kiyono M, Takafumi H, Tsujino R, Agetsuma N. 2007. Mature leaf selection of Japanese macaques: effects of availability and chemical content. J Zool 273: 140-147.

546 Hanya G, Noma N, Agetsuma N. 2003a. Altitudinal and seasonal variations in the diet of Japanese macaques in Yakushima. Primates 44: 51-59.

548 Hanya G, Stevenson P, van Noordwijk M, Wong ST, Kanamori T, Kuze N, Aiba S, 

frugivorous primate biomass and species richness. Ecography 34: 1009-1017.

552 Hanya G, Yoshihiro S, Zamma K, Kubo R, Takahata Y. 2003b. New method to census primate groups: estimating group density of Japanese macaques by point census. Am J Primatol 60: 43-56.

Hanya G, Yoshihiro S, Zamma K, Matsubara H, Ohtake M, Kubo R, Noma N, Agetsuma N, Takahata Y. 2004. Environmental determinants of the altitudinal variations in relative group densities of Japanese macaques on Yakushima. Ecol Res 19: 485-493.

Hill DA. 1997. Seasonal variation in the feeding behavior and diet of Japanese macaques (Macaca fuscata yakui) in lowland forest of Yakushima. Am J Primatol 43: 305-322.

Howe HF. 1986. Seed dispersal by fruit-eating birds and mammals. In: Murray DR, editor. Seed Dispersal. Sydney: Academic Press. p 123-190

Kleiber M. 1987. The Fire of Life. Florida: Robert E. Krieger Publishing Company.

Koda R, Noma N, Tsujino R, Umeki K, Fujita N. 2008. Effects of sika deer (Cervus nippon yakushimae) population growth on saplings in an evergreen broad-leaved forest. For Ecol Manage 256: 431-437.

Koenig A. 2002. Competition for resources and its behavioral consequences among female primates. International Journal of Primatology 23: 759-783.

571 Kominami Y, Sato T, Takeshita K, Manabe T, Endo A, Noma N. 2003. Classification of bird-dispersed plants by fruiting phenology, fruit size, and growth form in a primary lucidophyllous forest: an analysis, with 
implications for the conservation of fruit-bird interactions. Ornithological Science 2 3-23.

576

577

578

579

580

581

582

583

584

585

586

587

588

589

590

591

592

593

594

595

596

597

598

Landsberg J, Ohmart C. 1989. Levels of insect defoliation in forests: Patterns and concepts. Trends Ecol Evol 4: 96-100.

Moegenburg SM, Levey DJ. 2003. Do frugivores respond to fruit harvest? An experimental study of short-term responses. Ecology 84: 2600-2612.

Noma N, Yumoto T. 1997. Fruiting phenology of animal-dispersed plants in response to winter migration of frugivores in a warm temperate forest on Yakushima Island, Japan. Ecol Res 12: 119-129.

Nuñez-Iturri G, Howe HF. 2007. Bushmeat and the fate of trees with seeds dispersed by large primates in a lowland rain forest in western Amazonia. Biotropica 39: 348-354.

Otani T. 2001. Measuring fig foraging frequency of the Yakushima macaque by using automatic cameras. Ecol Res 16: 49-54.

Otani T, Shibata E. 2000. Seed dispersal and predation by Yakushima macaques, Macaca fuscata yakui, in a warm temperate forest of Yakushima Island, southern Japan. Ecol Res 15: 133-144.

Peres CA, Dolman PM. 2000. Density compensation in neotropical primate communities: evidence from 56 hunted and nonhunted Amazonian forests of varying productivity. Oecologia 122: 175-189.

Primack RB. 1995. A Primer of Conservation Biology. Sunderland: Sinauer Associates.

Reich PB, Oleksyn J, Modrzynski J, Tjoelker MG. 1996. Evidence that longer needle retention of spruce and pine populations at high elevations and high latitudes is largely a phenotypic response. Tree Physiol 16: 643-647. 
599 Rooke T, Bergstrom R. 2007. Growth, chemical responses and herbivory after

600 simulated leaf browsing in Combretum apiculatum. Plant Ecol 189:

601 201-212.

602

Rosenfeld JS. 2002. Functional redundancy in ecology and conservation. Oikos

603 98: 156-162.

604

605

606

607

608

609

610

611

612

613

614

615

616

617

618

619

620

621

622

623

Snaith TV, Chapman CA. 2007. Primate group size and interpreting sociolecological models: Do folivores really play by different rules? Evol Anthropol 16: 94-106.

Stevenson PR. 2001. The relationship between fruit production and primate abundance in Neotropical communities. Biol J Linnean Soc 72: 161-178.

Sun IF, Chen YY, Hubbell SP, Wright SJ, Noor NSM. 2007. Seed predation during general flowering events of varying magnitude in a Malaysian rain forest. J Ecol 95: 818-827.

Terakawa M, Isagi Y, Matsui K, Yumoto T. 2009. Microsatellite analysis of the maternal origin of Myrica rubra seeds in the feces of Japanese macaques. Ecol Res 24: 663-670.

Terakawa M, Matsui K, Hamada T, Noma N, Yumoto T. 2008. Reduced seed dispersal effectiveness in the large-seeded tree Myrica rubra in the absence of the Japanese macaque on Tanegashima Island, Japan (in Japanese). Jpn J Cons Ecol 13: 161-167.

Tsuji Y, Fujita S, Sugiura H, Saito C, Takatsuki S. 2006. Long-term variation in fruiting and the food habits of wild Japanese macaques on Kinkazan Island, northern Japan. Am J Primatol 68: 1068-1080.

Tsujino R, Yumoto T. 2009. Topography-specific seed dispersal by Japanese macaques in a lowland forest on Yakushima Island, Japan. J Anim Ecol 
Hanya et al.

78: $119-125$.

625 Vergutz L, Manzoni S, Porporato A, Novais RF, Jackson RB. 2012. Global

626 resorption efficiencies and concentrations of carbon and nutrients in

627 leaves of terrestrial plants. Ecol Monogr 82: 205-220.

628 Watanabe T. 1975. Some features of the wild Japanese monkeys (Macaca

629 fuscata) of Shiga A troop from viewpoint of somatometry. Physiology and

$630 \quad$ Ecology 16: 55-63.

631 Yoshihiro S, Ohtake M, Matsubara H, Zamma K, Hanya G, Tanimura Y, Kubota H,

632 Kubo R, Arakane T, Hirata T, Furukawa M, Sato A, Takahata Y. 1999.

633 Vertical distribution of wild Yakushima macaques (Macaca fuscata yakui) in the western area of Yakushima Island, Japan: Preliminary report. Primates 40: 409-415.

636 Yumoto T. 1987. Pollination systems in a warm temperate evergreen broad-leaved forest on Yaku Island. Ecol Res 2: 133-145.

638 Yumoto T, Noma N, Maruhashi T. 1998. Cheek-pouch dispersal of seeds by 639 Japanese monkeys (Macaca fuscata yakui) on Yakushima Island, Japan.

$640 \quad$ Primates 39: 325-338.

641

642 
Hanya et al. Primate impact -27 -

644 Legend to the figure

645 Fig. 1. Map of Yakushima showing lowland and highland study sites. Contours $646 \quad$ are drawn every $300 \mathrm{~m}$.

647 
Hanya et al.

Primate impact

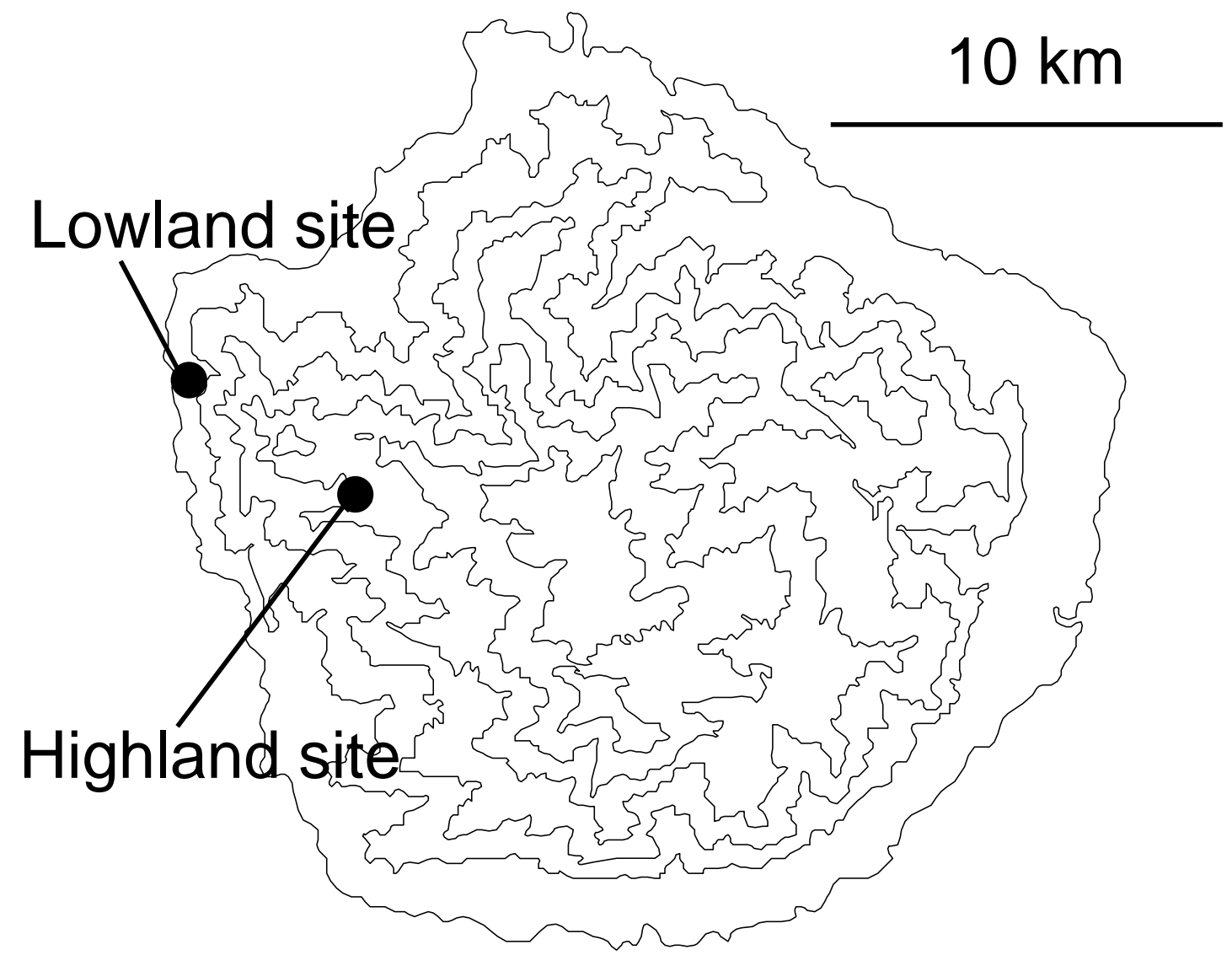

649 Fig. 1

650 
Hanya et al.

Primate impact

Table 1. Comparison of leaf consumption by macaques and estimated leaf production

a. Lowland forest of Yakushima

\begin{tabular}{|c|c|c|c|c|}
\hline \multirow[t]{2}{*}{ Target } & Leaf fall & $\begin{array}{l}\text { Corrected } \\
\text { leaf fall* }\end{array}$ & $\begin{array}{c}\text { Corrected } \\
\text { leaf } \\
\text { fall+estimate } \\
d \\
\text { consumption } \\
\text { by insects }\end{array}$ & $\begin{array}{l}\text { Leaf consumption by } \\
\text { macaques }\end{array}$ \\
\hline & $\mathrm{kg} / \mathrm{km}^{2} /$ year & $\mathrm{kg} / \mathrm{km}^{2} /$ year & $\mathrm{kg} / \mathrm{km}^{2} /$ year & $\begin{array}{c}\mathrm{kg} / \mathrm{km}^{2} / \text { year } \\
\text { (\% to leaf production) }\end{array}$ \\
\hline All species & 431000 & 544000 & 605000 & $\begin{array}{c}226 \\
(0.037 \%)\end{array}$ \\
\hline Food species & 76100 & 96100 & 107000 & $\begin{array}{c}226 \\
(0.21 \%)\end{array}$ \\
\hline Symplocos lucida & 1480 & 1870 & 2120 & $\begin{array}{c}35 \\
(1.7 \%)\end{array}$ \\
\hline Daphniphyllum teijsmannii & 410 & 518 & 614 & $\begin{array}{c}35 \\
(5.7 \%) \\
\end{array}$ \\
\hline \multicolumn{5}{|c|}{ b. Highland forest of Yakushima } \\
\hline \multirow[t]{2}{*}{ Target } & Leaf fall & $\begin{array}{l}\text { Corrected } \\
\text { leaf fall* }\end{array}$ & $\begin{array}{c}\text { Corrected } \\
\text { leaf } \\
\text { fall+estimate } \\
d \\
\text { consumption } \\
\text { by insects** }\end{array}$ & $\begin{array}{c}\text { Leaf consumption by } \\
\text { macaques }\end{array}$ \\
\hline & $\mathrm{kg} / \mathrm{km}^{2} /$ year & $\mathrm{kg} / \mathrm{km}^{2} /$ year & $\mathrm{kg} / \mathrm{km}^{2} /$ year & $\begin{array}{c}\mathrm{kg} / \mathrm{km}^{2} / \text { year } \\
\text { (\% to leaf production) }\end{array}$ \\
\hline All species & 352000 & 444000 & 495000 & $\begin{array}{c}1910 \\
(0.39 \%)\end{array}$ \\
\hline Food species & 150000 & 189000 & 212000 & $\begin{array}{c}1910 \\
(0.90 \%)\end{array}$ \\
\hline Symplocos myrtacea & 12100 & 15300 & 17200 & $\begin{array}{c}160 \\
(0.93 \%)\end{array}$ \\
\hline Eurya japonica & 4230 & 5340 & 6080 & $\begin{array}{c}130 \\
(2.1 \%)\end{array}$ \\
\hline Trochodendron aralioides & 36600 & 46200 & 51400 & $\begin{array}{c}78.2 \\
(1.5 \%)\end{array}$ \\
\hline Symplocos prunifolia & 81.3 & 103 & 129 & $\begin{array}{c}13 \\
(10 \%)\end{array}$ \\
\hline
\end{tabular}

* Corrected leaf fall was calculated by dividing the gross leaf fall by 0.792 , which indicated estimated leaf weight before the translocation of organic and inorganic matter from the abscised leaves.

$651 * *$ Insect folivory was assumed to be $10 \%$ of the leaf production. 
Hanya et al.

Primate impact

Table 2. Number of species decreasing/not decreasing over 13 years

a. Lowland forest of Yakushima (between 1990 and 2003)

\begin{tabular}{lcc}
\hline & Decrease & Not decrease \\
\hline Food species & 2 & 3 \\
Non-food species & 10 & 32 \\
\hline
\end{tabular}

a. Highland forest of Yakushima (between 1999 and 2012)

\section{Food species}

Decrease Not decrease

654

Non-food species

0
3

655 
Hanya et al.

Table 3. Comparison of fruit/seed consumption by Japanese macaques and birds to amount of fruit litter

a. Lowland forest of Yakushima

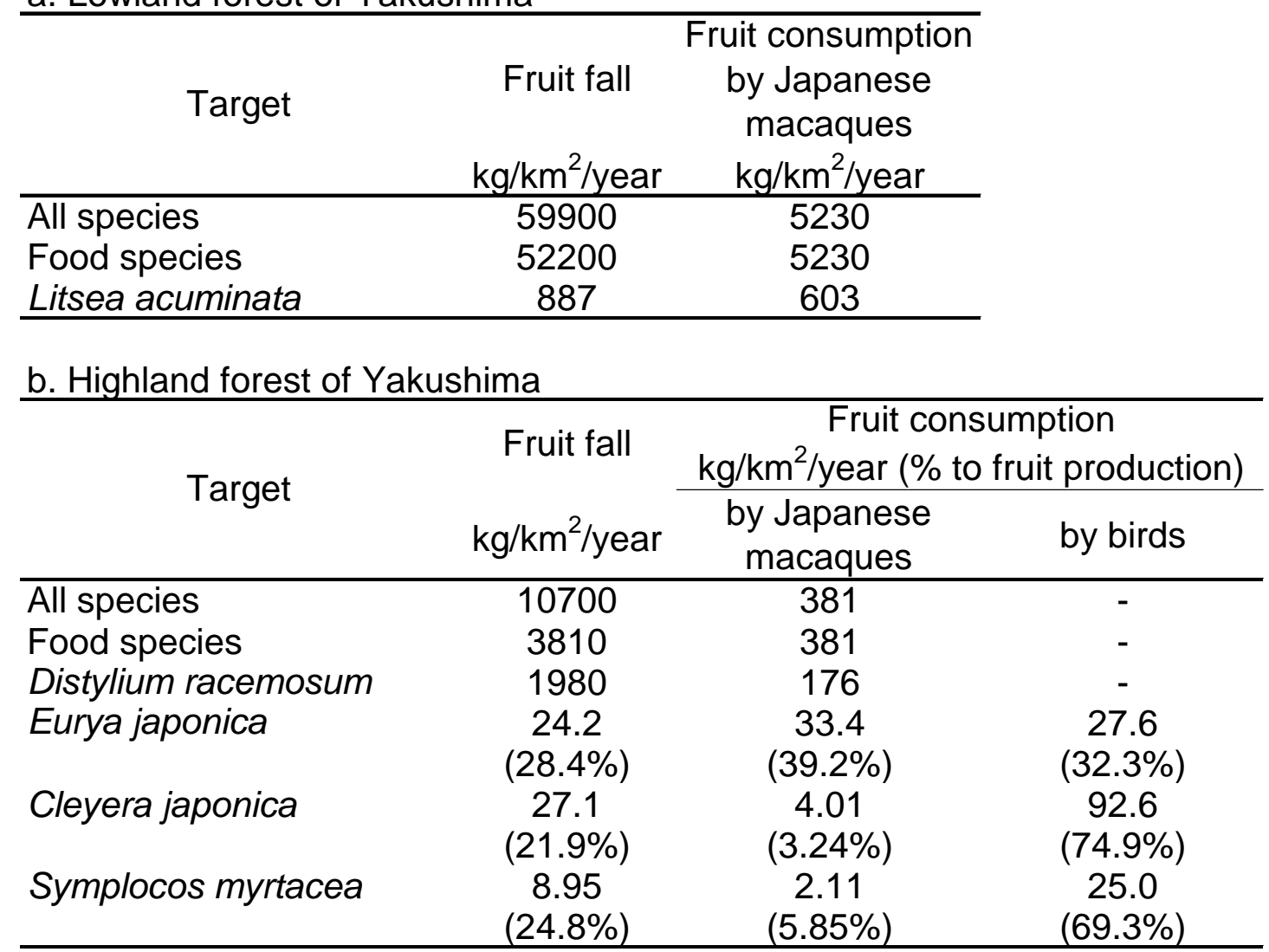


Hanya et al. Primate ecosystem impact Appendix 1

Appendix 1. Diet composition of the three study groups

\begin{tabular}{|c|c|c|c|c|c|c|}
\hline & \multicolumn{2}{|r|}{ HR } & \multicolumn{2}{|r|}{ NA } & \multicolumn{2}{|c|}{$\mathrm{H}$ (September only) } \\
\hline & $\begin{array}{c}\% \\
\text { feeding } \\
\text { time }\end{array}$ & $\begin{array}{l}\text { intake g dry } \\
\text { weight/h }\end{array}$ & $\begin{array}{l}\% \\
\text { feeding } \\
\text { time }\end{array}$ & $\begin{array}{l}\text { intake g dry } \\
\text { weight/h }\end{array}$ & $\begin{array}{c}\% \\
\text { feeding } \\
\text { time }\end{array}$ & $\begin{array}{l}\text { intake g dry } \\
\text { weight/h }\end{array}$ \\
\hline Fruit & $13 \%$ & 3.74 & $34 \%$ & 11.35 & $39 \%$ & 7.03 \\
\hline Seed & $4 \%$ & 1.89 & $32 \%$ & 8.40 & $52 \%$ & 3.95 \\
\hline Mature leaf & $38 \%$ & 12.76 & $5 \%$ & 0.67 & $2 \%$ & 0.09 \\
\hline Young leaf & $3 \%$ & 0.24 & $2 \%$ & 0.19 & $0 \%$ & 0.01 \\
\hline Flower & $15 \%$ & Not estimated & $2 \%$ & Not estimated & $0 \%$ & Not estimated \\
\hline Pith, stem, bark and roc & $4 \%$ & Not estimated & $2 \%$ & Not estimated & $2 \%$ & Not estimated \\
\hline Fungi & $14 \%$ & Not estimated & $1 \%$ & Not estimated & $0 \%$ & Not estimated \\
\hline Animal & $1 \%$ & Not estimated & $18 \%$ & Not estimated & $5 \%$ & Not estimated \\
\hline Other & $7 \%$ & Not estimated & $3 \%$ & Not estimated & $1 \%$ & Not estimated \\
\hline
\end{tabular}


Hanya et al. Primate ecosystem impact

Appendix 2

Appendix 2. Estimated unit weights, feeding rates, and percentage of feeding time for plants consumed by Japanese macaques living in lowland and highland forest areas

a. Lowland of Yakushima

\begin{tabular}{|c|c|c|c|c|}
\hline Category & Species & $\begin{array}{c}\text { Unit } \\
\text { weight (g) }\end{array}$ & $\begin{array}{c}\text { Feeding } \\
\text { rate } \\
\text { (\#unit/sec) }\end{array}$ & $\begin{array}{c}\% \text { to total } \\
\text { feeding } \\
\text { time }\end{array}$ \\
\hline fruit & Ficus superba & 0.150 & 0.22 & $9.0 \%$ \\
\hline fruit & Ficus erecta & 0.152 & 0.29 & $7.0 \%$ \\
\hline fruit & Eurya emarginata & 0.019 & 0.60 & $4.5 \%$ \\
\hline fruit & Actinidia rufa & 0.920 & 0.05 & $2.4 \%$ \\
\hline fruit & Ficus microcarpa & 0.148 & 0.15 & $2.2 \%$ \\
\hline fruit & Myrica rubra & 0.067 & 0.10 & $2.1 \%$ \\
\hline fruit & Litsea acuminata & 0.395 & 0.35 & $1.9 \%$ \\
\hline fruit & Ficus pumila & 0.352 & 0.03 & $1.6 \%$ \\
\hline fruit & Neolitsea sericea & 0.147 & 0.25 & $1.1 \%$ \\
\hline fruit & Morinda umbellata & 0.088 & 0.47 & $0.9 \%$ \\
\hline fruit & Vitis ficifolia & 0.013 & 0.27 & $0.6 \%$ \\
\hline fruit & Melia azedarach & 0.405 & NA & $0.6 \%$ \\
\hline fruit & Cinnamomum camphora & 0.048 & 0.28 & $0.4 \%$ \\
\hline fruit & Eurya japonica & 0.012 & 0.63 & $0.4 \%$ \\
\hline fruit & Diospyros japonica & 0.352 & 0.10 & $0.4 \%$ \\
\hline fruit & Elaeocarpus sylvestris & 0.356 & 0.09 & $0.2 \%$ \\
\hline fruit & Psychotria serpens & 0.008 & 0.10 & $0.2 \%$ \\
\hline fruit & Taxillus yadoriki & 0.041 & 0.10 & $0.1 \%$ \\
\hline fruit & Glochidion obovatum & 0.195 & NA & $0.1 \%$ \\
\hline fruit & Ardisia sieboldii & 0.055 & 0.21 & $0.1 \%$ \\
\hline mature leaf & Daphniphyllum teijsmannii & 0.110 & 0.07 & $1.9 \%$ \\
\hline mature leaf & Symplocos lucida & 0.110 & 0.17 & $0.6 \%$ \\
\hline mature leaf & Oreocnide pedunculata & 0.022 & 0.34 & $0.4 \%$ \\
\hline mature leaf & Ficus superba & 0.270 & 0.11 & $0.4 \%$ \\
\hline mature leaf & Trema orientalis & 0.230 & 0.07 & $0.4 \%$ \\
\hline mature leaf & Ficus erecta & 0.170 & 0.06 & $0.2 \%$ \\
\hline mature leaf & Callicarpa shikokiana & 0.022 & 0.43 & $0.2 \%$ \\
\hline mature leaf & Maesa tenera & 0.120 & 0.11 & $0.1 \%$ \\
\hline mature leaf & Hydrangea grosseserrata & 0.037 & NA & $0.1 \%$ \\
\hline seed & Rhus succedanea & 0.093 & 0.42 & $8.8 \%$ \\
\hline seed & Zanthoxylum ailanthoides & 0.007 & 0.81 & $5.4 \%$ \\
\hline seed & Rhaphiolepis umbellata & 0.195 & 0.22 & $4.3 \%$ \\
\hline seed & Lithocarpus edulis & 0.386 & 0.06 & $3.8 \%$ \\
\hline seed & Cinnamomum camphora & 0.048 & 0.45 & $3.1 \%$ \\
\hline seed & Mallotus japonicus & 0.009 & 0.48 & $2.4 \%$ \\
\hline seed & Ardisia sieboldii & 0.055 & 0.28 & $0.8 \%$ \\
\hline seed & Litsea acuminata & 0.001 & 0.25 & $0.7 \%$ \\
\hline seed & Quercus phillyraeoides & 0.490 & 0.12 & $0.7 \%$ \\
\hline seed & Oreocnide pedunculata & 0.007 & 0.49 & $0.6 \%$ \\
\hline seed & Euscaphis japonica & 0.030 & 0.23 & $0.6 \%$ \\
\hline seed & Neolitsea sericea & 0.147 & 0.36 & $0.2 \%$ \\
\hline seed & Castanopsis sieboldii & 0.498 & NA & $0.2 \%$ \\
\hline seed & Glochidion obovatum & 0.195 & NA & $0.1 \%$ \\
\hline young leaf & Rhus succedanea & 0.039 & 0.14 & $1.2 \%$ \\
\hline young leaf & Elaeagnus glabra & 0.044 & 0.40 & $0.2 \%$ \\
\hline young leaf & Oreocnide pedunculata & 0.006 & 0.64 & $0.1 \%$ \\
\hline
\end{tabular}


Hanya et al. Primate ecosystem impact

Appendix 2

b. Highland of Yakushima

\begin{tabular}{|c|c|c|c|c|}
\hline Category & Species & $\begin{array}{c}\text { Unit } \\
\text { weight (g) }\end{array}$ & $\begin{array}{c}\text { Feeding } \\
\text { rate } \\
\text { (\#unit/sec) }\end{array}$ & $\begin{array}{c}\% \text { to total } \\
\text { feeding } \\
\text { time }\end{array}$ \\
\hline fruit & Eurya japonica & 0.012 & 1.01 & $5.2 \%$ \\
\hline fruit & Prunus sargentii & 0.082 & 0.30 & $2.4 \%$ \\
\hline fruit & Boehmeria longispica & 0.067 & 0.38 & $1.7 \%$ \\
\hline fruit & Eurya japonica var. yakushimensis & 0.008 & 0.71 & $0.9 \%$ \\
\hline fruit & Cornus kousa & 0.700 & 0.14 & $0.8 \%$ \\
\hline fruit & Cleyera japonica & 0.038 & 0.52 & $0.4 \%$ \\
\hline fruit & Dendropanax trifidus & 0.030 & 0.34 & $0.3 \%$ \\
\hline fruit & Symplocos myrtacea & 0.030 & 0.51 & $0.3 \%$ \\
\hline fruit & Neolitsea aciculata & 0.036 & 0.50 & $0.2 \%$ \\
\hline fruit & Vitis ficifolia & 0.042 & 0.17 & $0.2 \%$ \\
\hline fruit & Ilex pedunculosa & 0.074 & 0.16 & $0.2 \%$ \\
\hline fruit & Euonymus yakushimensis & 0.018 & 0.27 & $0.2 \%$ \\
\hline fruit & Ilex crenata & 0.065 & 0.55 & $0.2 \%$ \\
\hline mature leaf & Symplocos myrtacea & 0.039 & 0.56 & $12.5 \%$ \\
\hline mature leaf & Eurya japonica & 0.118 & 0.34 & $5.3 \%$ \\
\hline mature leaf & Histiopteris incisa & 0.123 & 0.25 & $4.0 \%$ \\
\hline mature leaf & Actinidia arguta & 0.103 & 0.24 & $3.3 \%$ \\
\hline mature leaf & Symplocos prunifolia & 0.055 & 0.20 & $2.2 \%$ \\
\hline mature leaf & Sorbus commixta & 0.045 & 0.60 & $1.7 \%$ \\
\hline mature leaf & Rubus croceacanthus & 0.008 & 0.61 & $1.5 \%$ \\
\hline mature leaf & Lepisorus onoei & 0.066 & 0.59 & $1.5 \%$ \\
\hline mature leaf & Trochodendron aralioides & 0.325 & 0.12 & $1.1 \%$ \\
\hline mature leaf & Rubus minusculus & 0.035 & 0.58 & $1.0 \%$ \\
\hline mature leaf & Ficus oxyphylla & 0.075 & 0.17 & $0.8 \%$ \\
\hline mature leaf & Mitchella undulata & 0.008 & 0.76 & $0.8 \%$ \\
\hline mature leaf & Pyrrosia lingua & 0.133 & 0.05 & $0.4 \%$ \\
\hline mature leaf & Zoysia japonica & 0.007 & 0.77 & $0.4 \%$ \\
\hline mature leaf & Miscanthus sinensis & 0.034 & 0.87 & $0.3 \%$ \\
\hline mature leaf & Chloranthus serratus & 0.074 & 0.27 & $0.3 \%$ \\
\hline mature leaf & Gleichenia japonica & 0.123 & 0.23 & $0.2 \%$ \\
\hline mature leaf & Ilex pedunculosa & 0.100 & 0.23 & $0.1 \%$ \\
\hline mature leaf & Clethra barbinervis & 0.103 & 0.38 & $0.1 \%$ \\
\hline seed & Distylium racemosum & 0.001 & 0.10 & $2.5 \%$ \\
\hline seed & Cornus kousa & 0.096 & 0.54 & $1.0 \%$ \\
\hline seed & Camellia japonica & 0.019 & 0.54 & $0.2 \%$ \\
\hline seed & Quercus salicina & 0.124 & 0.50 & $0.2 \%$ \\
\hline young leaf & Symplocos myrtacea & 0.779 & 0.00 & $2.9 \%$ \\
\hline young leaf & Actinidia arguta & 1.022 & 0.02 & $0.4 \%$ \\
\hline
\end{tabular}


Hanya et al. Primate ecosystem impact

Appendix 3. Parameters used in the estimation of the population-level food consumption by Japanese macaques

a. Average day length of each month

\begin{tabular}{cc}
\hline Month & $\begin{array}{c}\text { Day length } \\
\text { (hour) }\end{array}$ \\
\hline January & 13.0 \\
February & 13.2 \\
March & 14.2 \\
April & 14.0 \\
May & 13.3 \\
June & 12.5 \\
July & 11.5 \\
August & 10.7 \\
September & 10.2 \\
October & 10.3 \\
November & 11.1 \\
December & 12.0 \\
\hline
\end{tabular}

b. Parameters specific to different age-sex categories

\begin{tabular}{ccccc}
\hline Category & $\begin{array}{c}\text { Body mass } \\
(\mathrm{kg})\end{array}$ & $\begin{array}{c}\text { Energy } \\
\text { requirement } \\
\text { relative to an } \\
\text { adult female }\end{array}$ & $\begin{array}{c}\text { Proportion in } \\
\text { the population } \\
\text { (NA group) }\end{array}$ & $\begin{array}{c}\text { Proportion in } \\
\text { the population } \\
\text { (HR group) }\end{array}$ \\
\hline Adult male & 15.39 & 1.10 & $16 \%$ & $25 \%$ \\
Adule female & 13.55 & 1 & $28 \%$ & $35 \%$ \\
Juvenile & 6.54 & 0.58 & $56 \%$ & $32 \%$ \\
Infant & $\mathrm{NA}$ & 0 & $0 \%$ & $8 \%$ \\
\hline
\end{tabular}

c. Abundance of Japanese macaques

\begin{tabular}{lc}
\hline \multicolumn{1}{c}{ Site } & $\begin{array}{c}\text { Population } \\
\text { density } \\
\text { (macaque/km² }\end{array}$ \\
\hline Lowland & 81.1 \\
Highland & 11.8 \\
\hline
\end{tabular}

